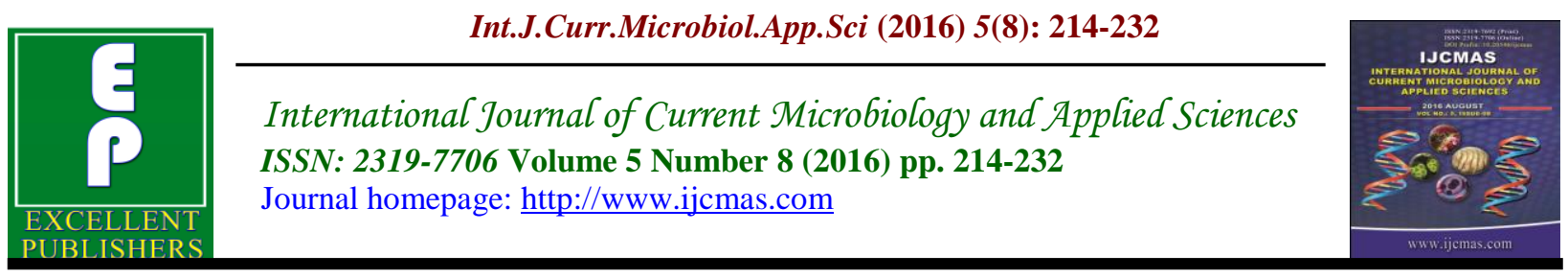

Original Research Article

http://dx.doi.org/10.20546/ijcmas.2016.508.023

\title{
Isolation and Characterization of Lipase producing Bacteria from Vegetable Oil Spillage Site
}

\author{
Miral Patel*, Jemisha Mistry, Suraj Desai, Swetal Patel and Shreya Desai \\ C.G. Bhakta Institute of Biotechnology, Uka Tarsadia University, Maliba campus, \\ Bardoli, Surat, 394350, Gujarat, India \\ *Corresponding author
}

\begin{abstract}
A B S T R A C T
Keywords

Lipolytic

Activity,

zone of

hydrolysis.

Article Info

Accepted:

12 July 2016

Available Online:

10 August 2016

Study was conducted to isolate the lipase producing bacteria and characterize the lipase enzyme for its optimal activity. The samples were collected from vegetable oil spillage site. A total of 26 isolates producing lipase were isolated from three different samples processed. Lipolytic activity was confirmed by observing the zone of hydrolysis formed around the growth of colony on TBA plate. Out of 26 isolates, 4 isolates, viz $\mathrm{A} 2, \mathrm{~B} 4, \mathrm{C} 1$ and $\mathrm{C} 2$ having zone diameter more than $1 \mathrm{~mm}$ were considered to be potential isolates and were subjected for further characterization. Lipase was quantified by determining the EU/ml by butyric acid titrimetric assay. All the potential isolates were also subjected to morphological and biochemical characterization for their partial identification. B4 and $\mathrm{C} 1$ isolates from 4 selected isolates were Gram positive while remaining A2 and C2 were Gram negative. Isolate B4 and $\mathrm{C} 1$ were identified as belongs to genus Bacillus, while other isolates required further characterization for their identification. Lipase enzyme produced by these potential isolates was also characterized for determining its optimal activity. Effect of different $\mathrm{pH}$ and temperature on lipase activity was determined. The optimum $\mathrm{pH}$ for $\mathrm{A} 2, \mathrm{~B} 4, \mathrm{C} 1$ and $\mathrm{C} 2$ was found to be 7.5, 8, 8 and 7.5 respectively, while the optimum temperature for lipase activity for A2, B4, C1 \& C2 was found to be $37^{\circ} \mathrm{C}$ respectively.
\end{abstract}

\section{Introduction}

\section{Lipases}

Lipids are key elements in the chemistry of life. Most organisms use the supramolecular chemistry inherent to phospholipids to form their exterior and compartmental membranes. Many plants and animals store chemical energy in the form of triglycerides, which are sparingly soluble in water (Schmid and Verger, 1998).
To be able to carry out these functions, lipids require lipolytic enzymes during their metabolism. Lipolytic enzymes catalyze the turnover of these water-insoluble compounds (Gilham and Lehner, 2005).

Lipase is defined by the enzyme commission of International Union Of Biochemistry and Molecular Biology (IUBMB) as the enzyme that catalyzes hydrolysis of ester bonds at 
the interface between an insoluble substrate phase and the aqueous phase in which the enzyme is dissolved, under a natural conditions. Under certain experimental conditions, such as in the absence of water, they are capable of reversing the reaction. The reverse reactions lead to esterification and formation of glycerides from fatty acids and glycerol (Jaeger et al., 2002).

According to Enzyme Nomenclature given by International Union of Biochemistry and Molecular Biology (IUBMB), Lipolytic enzymes are grouped into 2 main categories, those which can hydrolyze triglycerides at the water/oil boundary are termed lipases or, more systematically, triacylglycerol hydrolases, and those which attack phospholipids are termed Phospholipases (Schmid and Verger, 1998) .

Both types of enzymes have recently received considerable attention; phospholipases are involved in key metabolic events such as membrane turnover and signal transduction, lipases have diverse functions in the degradation of food and fat; they have qualified as valuable drugs against digestive disorders and diseases of the pancreas. They also find applications in biotechnology (in particular as detergent additives) and as catalysts for the manufacture of specialty (oleo) chemicals and for organic synthesis (Schmid and Verger, 1998).

Now a day, lipase arises amongst the most important biocatalysts carrying out novel reactions in aqueous and non-aqueous media. This is mainly due to the their ability to utilize a wide spectrum of substrates, high stability towards extremes of temperature, $\mathrm{pH}$ and organic solvents, and show chemoregio- and enantio-selectivity. In recent times, the determination of their three dimensional structures has thrown light in to their unique structure- function relationship (Berglunnd, 2001).

Lipases were first discovered in 1856 by Claude Bernard when he studied the role of the pancreas in fat digestion (Peterson and Drabløs, 1994). Since then, many different lipases have been identified in and isolated from bacteria, fungi, plants, and animals. The presence of lipases has been noticed as early as in 1901 for Bacillus prodigiosus, $B$. pyocyaneus and $B$. fluorescens which are now called Serratia marcescens, Pseudomonas aeruginosa and Pseudomonas fluorescens, respectively (Jaeger et al., 1999; Hasan et al., 2006).

It is very important to know threedimensional structures of lipases in order to make them fit for specific applications. Human pancreatic lipase and the lipase from the fungus Rhizomucor miehei were the first ones whose 3D structures elucidated. Various other fungal and bacterial lipase structures were determined slowly. The first bacterial lipase structure, from Pseudomonas glumae, was clarified in 1993 (Noble et al., 1993).

\section{Sources of Lipases}

Lipases are found throughout all kingdoms of life, which are prokaryotes including bacteria and archaea and eukaryotes including plants, animals and fungi (Caihong et al., 2008). However, lipases of microbial origin are the most versatile enzymes and are known to bring about a range of bioconversion reaction including alcoholysis, aminolysis, hydrolysis, esterification and interesterification (Pandey et al., 1990). Besides, microbes can be easily cultivated and the lipases produced are mostly extracellular. Several Bacillus sp. have been reported to be the main source of lipolytic enzyme (Schmidt et al., 1994). 
Lipase producers have been isolated mainly from soil, or spoiled food material that contains vegetable oil. Lipase production from a variety of bacteria, fungi and actinomycetes has been reported in several works (Sztajer et al., 1988; Kulkarni and Gadre, 2002).

\section{Bacterial Lipases}

Bacterial enzymes are more preferred over fungal enzymes because of their higher activities and neutral or alkaline $\mathrm{pH}$ optima. In order to increase the cell yields and the enzymatic activities of the cells or to produce altered enzymes, genetic and environmental manipulations can be performed more readily on bacterial cells due to their short generation times, their simple nutritional needs and easy screening procedures for desired properties (Hasan et al., 2006).

A variety of lipases are produced from both Gram-positive and Gram-negative bacteria. Greater part of bacterial lipases comes from Gram-negative bacteria and the most important Gram-negative genus is Pseudomonas which contains at least seven lipase producing species that are $P$. aeruginosa, $P$. alcaligenes, $P$. fragi, $P$. glumae, P. cepacia, P. fluorescens and $P$. putida (Kojima et al., 2003). Besides Pseudomonas species Achromobacter, Alcaligenes, Burkholderia and Chromobacterium strains are the most common lipase producing gram-negatives (Gupta and Rathi, 2004).

Gram-positive lipase producers are Staphylococcus (especially, S.aureus and S.hyicus), Streptomyces and Bacillus species. The most useful lipase producer genus used in industry is Bacillus among Gram-positive bacteria (Jaeger et al., 1994).

\section{Detection of Lipase Producing Microorganisms}

There must be three factors to detect a lipase-positive bacterium by culturing it. These factors include (i) growth of the organism, (ii) production of lipase by that organism under suitable growth conditions and (iii) the presence of a sensitive method to detect lipase activity (Shelley et al., 1987).

Microorganisms are often tested for lipase production on solid media. All methods containing agar can be grouped into two categories; (1) Methods based on substrate changes in appearance as a result of lipolysis and (2) methods including the usage of an indicator dye to detect lipolysis (Thomson et al., 1999).

It is possible to visualize lipase-producing microbial colonies on solid media depending on the used lipase substrate. A diffusion assay can be used to identify lipaseproducing microorganisms. In this method, a growth medium with tributyrin or triolein is prepared and microbial culture is put into wells cut in the agar. Lipase activity is defined by a clear zone formation around colonies after incubation (Thomson et al., 1999; Shelley et al., 1987) concluded that agar media can be useful for only screening of lipase production, but not to measure lipase activity.

\section{Parameters for Optimum Lipase Production}

Bacterial lipases are mostly extracellular and are greatly influenced by nutritional and physico-chemical factors, such as temperature, $\mathrm{pH}$, nitrogen and carbon sources, presence of lipids, inorganic salts, agitation and dissolved oxygen concentration (Brune and Gotz, 1992; Jaeger et al., 1994). 
The major factor for the expression of lipase activity has always been carbon, since lipases are by and large inducible enzymes (Lotti et al., 1998) and are thus generally produced in the presence of a lipid source such as an oil or any other inducer, such as triacylglycerols, fatty acids, hydrolyzable esters, tweens, bile salts and glycerol (Ghosh et al., 1996).

Besides carbon source, the type of nitrogen source in the medium also influences the lipase titers in production broth (Ghosh et al., 1996). Generally, organic nitrogen is preferred, such as peptone and yeast extract, which have been used as nitrogen source for lipase production by various Bacillus and Pseudomonas spps (Wang et al., 1995). Divalent cations stimulate or inhibit enzyme production in microorganisms. Rathi et al., (2001) observed stimulation in lipase production from Burkholderia $\mathrm{sp}$. in the presence of $\mathrm{Ca}_{2}+$ and $\mathrm{Mg}_{2}+$.

In addition to the various chemical constituents of a production medium, physiological parameters such as $\mathrm{pH}$, temperature, agitation, aeration and incubation period also play an important role in influencing production by different microorganisms. The initial $\mathrm{pH}$ of the growth medium is important for lipase production. Largely, bacteria prefer $\mathrm{pH}$ around 7.0 for best growth and lipase production, such as in the case of Bacillus spps. (Sugihara et al., 1991), Acinetobacter spps. (Barbaro et al., 2001) and Burkholderia spps. (Rathi et al., 2001). However, maximum activity at higher $\mathrm{pH}$ (>7.0) has been observed in many cases (Nashif and Nelson 1953; Wang et al., 1995; Khyami-Horani 1996; Dong et al., 1999). The optimum temperature for lipase production corresponds with the growth temperature of the respective microorganism. For example, the best temperature for growth and lipase production in the case of Bacillus spps. was $50^{\circ} \mathrm{C}$ (Sharma et al., 2002). It has been observed that, in general, lipases are produced in the temperature range $20-45^{\circ} \mathrm{C}$. Incubation periods ranging from few hours to several days have been found to be best suited for maximum lipase production by bacteria. An incubation period of $12 \mathrm{~h}$ was optimum for lipase production by $A$. calcoaceticus and Bacillus spps. (Sharma et al., 2002). While maximum lipase was produced after $72 \mathrm{~h}$ and $96 \mathrm{~h}$ of incubation, respectively, in the case of the Pseudomonas spps. including P. fluorescens (Dong et al., 1999).

\section{Analytical Determination of Lipase}

Lipases are often analyzed by their hydrolytic action on triglycerides in a heterogeneous reaction medium of water and oil (Schmid and Verger, 1998).

\section{Applications of Lipases}

Microbial lipases have assumed a great deal of importance as industrial enzymes in view of their potential for use in various biotechnological purposes. Lipases are being exploited due to their low cost of extraction, thermal and $\mathrm{pH}$ stability, substrate specificity and activity in organic solvents. Lipases are the most widely used enzymes in organic synthesis and more than $20 \%$ biotransformations are performed with lipases (Gitleson et al., 1997). The field of industrial enzymes is now experiencing major $\mathrm{R}$ and $\mathrm{D}$ initiatives, resulting in both the development of a number of new products and in improvement in the process and performance of several existing products. Today nearly 4000 enzymes are known and out of these, about 200 are commercially used (Sharma et al., 2011).

In eukaryotes, lipases are involved in various stages of lipid metabolism including 
fat digestion, absorption, reconstitution and lipoprotein metabolism. Bacterial lipases are extensively used in food industry for quality improvement, dairy industry for hydrolysis of milk fat, cheese ripening, in beverages to improve aroma and in health foods for trans esterification. In detergent industry for removal of oil stains from fabrics by hydrolysis of fats, in textile industry to increase fabric absorbency. In addition the enzyme is used in chemical industry for enantioselectivity \& synthesis of different products. In pharmaceuticals monoglycerides are used as binders in tablets enabling slow drug release, for the synthesis of biodegradable polymers or compounds, in pulp and paper industry to improve quality, degreasing leather in leather industry and for the production of various products in cosmetic industry (Sumanjelin et al., 2013).

\section{Industrial Applications of Microbial Lipases}

Lipases found promising application in chemical processing, dairy industry, agrochemical industry, paper industry, oleochemical industry, cosmetics, pharmaceuticals, synthesis of surfactants, detergent industry, polymer synthesis and personal care products (Sharma et al., 2011). The lipases can be employed in industry by cultivating lipase producing microorganisms in the medium containing suitable substrate (especially in the food industry), Which is name in situ application or by using immobilized pure enzymes (especially in the production of fine chemicals) called as ex situ application (Pandey et al., 1999).

\section{Lipases in the food industry}

Lipases have become an integral part of the modern food industry. It is desirable for the production of flavours in cheese and for interesterification of fats and oils. It also accelerates the ripening of cheese and lipolysis of butter, fats and cream. Addition of lipases to such products primarily releases short-chain (C12 and C14) fatty acids leads to formation of a smooth taste (Saxena et al., 1999).

Lipases are also used as emulsifiers in food, pharmaceuticals and cosmetics industries (Fleming, 1991). Lipases are used for the production of maltose-and lactose-like sugar fatty acid esters.

Lipases are also commonly employed in dairy industry for the hydrolysis of milk fat. Improvement of flavor in cheeses, the acceleration of cheese ripening, the production of cheese like products and the lipolysis of butterfat and cream is achieved by the help of lipase enzymes. Lipases have been used to produce meat like fish meat without excess amount of fat. The fat is removed during the processing of the fish meat by adding lipases and this procedure is called biolipolysis (Sharma et al., 2001; Seitz, 1974).

\section{Lipases in the detergents}

The addition of lipases to detergent formulations has been investigated in the context of removal of fat stains (Schmid and R. Verger, 1998). Ever since the discovery of lipases it became part and parcel of the detergent industry along with proteases, amylases and cellulases. Lipases, protease, amylase and celluloses were used as they can split fats, proteins, starch and cottonfluff, respectively.

Nowadays they were extensively used in household detergent, industrial cleaner and leather processing. Lipase has also been used to clean clogged drain which is due to the food and non-food material deposition. 
In 1992, Novo Nordisk introduced the first commercial recombinant lipase 'Lipolase' originating from fungus Thermomyces lanuginose which was expressed in Aspergillus oryzae (Jaeger and Reetz, 1998). In addition to their application in laundry, lipases are also included in dish washing, contact lens cleaning, degradation of organic wastes on the surface of exhaust pipes and toilet bowls etc (Hasan et al., 2006).

\section{Lipases in pulp and paper industry}

Wood is the main source of paper and pulp industry and the presence of the hydrophobic components (mainly triglycerides and waxes), also name pitch, in wood causes serious problems in the production of paper and pulp. Lipases are used to remove the pitch from pulp produced for paper making. The enzymatic pitch control method using lipase was put into practice in a large-scale paper-making process as a routine operation in the early 1990s and was the first case in the world in which an enzyme was successfully applied in the actual paper-making process (Bajpai, 1999). Candida rugosa lipases were used by Nippon Paper Industry, Japan to develop a pitch control method to hydrolyse $90 \%$ of wood triglycerides (Reetz and Jaeger, 1998).

\section{Lipases in cosmetics and perfumery}

Lipases have potential application in cosmetics and perfumeries because it shows activities in surfactants and in aroma production (Metzger and Bornscheuer, 2006). Monoacyl glycerols and diacyl glycerols are produced by esterification of glycerols and are used as a surfactant in cosmetics and perfume industries.

\section{Lipases in leather industry}

The main process in leather industry is the removal of subcutaneous fat and dehairing.
Conventional methods including organic solvents and surfactants to remove fat from animal skins can be harmful to environment due to the production of dangerous final products like volatile organic compound (VOC) emissions (Hasan et al., 2006).

Usage of lipases in association with other hydrolytic enzymes like proteases is a new approach in leather processing. Since the process in carried out at alkaline $\mathrm{pH}$, alkalophilic lipases are used in combination with alkaline or neutral proteases and other necessary hydrolytic enzymes (Pandey et al., 1999).

\section{Lipases in bioremediation}

Employment of lipases in bioremediation process is a new aspect in lipase biotechnology. Oil spills in refinery, shore sand and processing factories could be handled by the use of lipases from different origins (Nakamura et al., 1994). It has been also used for the degradation of wastewater contaminants such as olive oil from oil mills. Another important application has been reported for the degradation of polyester waste and removal of biofilm deposits from cooling water systems (Sharma et al., 2011).

\section{Lipases as biosensors}

The quantitative determination of triacylglycerol is of great importance in clinical diagnosis and in food industry. The lipid sensing device as a biosensor are rather cheaper and less time consuming as compared to the chemical methods for the determination of triacylglycerols. An analytical biosensor was developed for the determination of lipids for the clinical diagnosis (Masahiko et al., 1995). Here, in quantitative determination of lipases are used to generate glycerol from 
triacylglycerol in the analytical sample and to quantify the released glycerol by enzymatic or chemical methods. This principle enabled the physician to diagnose the patients with cardiovascular complaint. C. rugusa lipase biosensor from Candida rugosa has been developed as a DNA probe (Benjamin and Pandey, 2001).

\section{Materials and Methods}

\section{Sample Collection}

Samples from vegetable oil spillage site were collected from hotel and restaurant along Bardoli area in a sterile container. The samples were then brought to the laboratory without further contamination. The samples were then processed for isolation of lipolytic bacteria.

\section{Screening for Lipase Production}

\section{Primary screening for lipase producing bacteria}

$1 \mathrm{gm}$ of each samples were dissolved in 10 gm of sterile distilled water and was serially diluted. Screening of lipase producers was carried out using tributyrin agar plates $(0.5 \%$ peptone, $0.3 \%$ yeast extract, $1 \%$ tributyrin and $2 \%$ agar, $\mathrm{pH} 7.0$ ) according to method described by Lawrence (1967) with slight modifications. The dilutions were then spread onto tributyrin agar plates and incubated at $37^{\circ} \mathrm{C}$ temperature for $24-48 \mathrm{hr}$.

Following incubation, the plates were observed for the zone of clearance around colonies, indicative of lipase activity. The zone diameters of all the positive isolates for lipase production were measured. All the potent isolates were then preserved on sterile NA slants under refrigeration for further studies.

Secondary screening to determine Enzyme Units by shake flask study
All the potent isolates with higher zone diameter were then subjected to shake flask study for determination of enzyme units produced by individual isolates.

\section{Lipase production}

Each potential isolates were inoculated in the $15 \mathrm{ml}$ of inoculum media (20 gm glucose, $10 \mathrm{gm}$ yeast extract, $10 \mathrm{gm}$ peptone, $10 \mathrm{gm} \mathrm{CH}_{3} \mathrm{COONa} .3 \mathrm{H}_{2} \mathrm{O}, 0.09 \mathrm{gm}$ $\mathrm{MgSO}_{4}, \quad 0.03 \mathrm{gm} \quad \mathrm{MnSo}_{4}, \quad 1.5 \mathrm{mg}$ $\mathrm{CuSO}_{4} .5 \mathrm{H}_{2} \mathrm{O}, 0.5 \mathrm{gm} \mathrm{KCL}, 5 \mathrm{ml}$ Olive oil, $1000 \mathrm{ml}$ Distilled water and $\mathrm{pH}$ 10.8). The inoculum flasks were then incubated at $37^{\circ}$ $\mathrm{C}$ temperature for overnight on rotary shaker at $100 \mathrm{rpm}$.

The actively growing inoculums of individual potent isolates were then transferred in to $135 \mathrm{ml}$ of production media (same as inoculums media but different in the olive oil concentration i.e. $20 \mathrm{ml}$ ). The production media flasks were then incubated at $37^{\circ} \mathrm{C}$ temperature for 24 hours on a rotary shaker at $120 \mathrm{rpm}$. After 24 hours of incubation, the culture was centrifuged at $10,000 \mathrm{rpm}$ for $20 \mathrm{~min}$ at $4^{\circ} \mathrm{C}$ and the cell free culture supernatant fluid was used as the crude extracellular enzyme for quantitative determination of enzyme units per ml.

\section{Lipase Assay}

Lipase activity was determined titrimetrically with modification of the method described by Arima et al., (1972). In the standard assay conditions, the substrate was prepared by emulsifying $2.5 \mathrm{ml}$ of tributyrin with $22.5 \mathrm{ml}$ of polyvinyl alcohol ( 2 gm polyvinyl alcohol was dissolved in 50 $\mathrm{ml}$ of distilled water using magnetic stirrer). Then $0.25 \mathrm{~m} 1$ of crude enzyme solution was added into the assay medium and the mixture was incubated for 30 minutes at 
$37^{0} \mathrm{C}$. The lipase reaction was terminated with the addition of $4 \mathrm{ml}$ of acetone-ethanol mixture $(1: 1 \mathrm{v} / \mathrm{v})$ into the reaction mixture. The amount of free fatty acids liberated during the incubation was titrated with 0.01 $\mathrm{N} \mathrm{NaOH}$ and $1 \%$ phenolphthalein as the indicator. One unit of lipase activity is defined as the amount of enzyme required to liberate $1 \mu \mathrm{M}$ of fatty acid per $\mathrm{ml}$ per minute under the specified conditions (such as incubation temperature etc.).

\section{Characterization of Isolates}

The potential isolates were further characterized for their partial identification. Morphological and biochemical characteristics of the isolate have been studied for the identification of the isolate. Bergey's Manual of Systematic Bacteriology ( $2^{\text {nd }}$ edition) was used as a reference for identification based on the result of various biochemical tests.

\section{Morphological characterization}

\section{Gram Staining}

Morphological characterization of the potential isolates involved use of Gram's staining. The cells were studied on the basis of their size, shape, arrangement and Gram reactivity. A smear of the selected strains were prepared on a clean glass slide and the smear was allowed to air-dry and then heat fixed. The heat-fixed smear was flooded with crystal violet and after one minute, it was washed with water and flooded with mordant Gram's iodine. The smear was decolorized with $95 \%$ ethyl alcohol, washed with water and then counter-stained with safranin for 45 seconds. After washing with water, the smear was dried with tissue paper and examined under oil immersion (100x).

\section{Cultural characterization}

The cultural characteristics such as size, shape, margin, elevation, surface, consistency, opacity and pigmentation were studied after growing the most potential isolates on nutrient agar plates

\section{Biochemical Characterization}

The biochemical test such as Sugar utilization test, IMViC test, Starch hydrolysis, Gelatin liquefaction, Nitrate reduction, Phenylalanine, TSI, Catalase, Lipid hydrolysis, Oxidase, Haemolysis and Indole production test were studied for their characterization.

Sugar Utilization test: A loopful culture of selected potential isolates were inoculated in to the sugar broth [10\% aqueous test sugar solution (glucose, maltose, lactose, mannitol, rhamnose, sucrose, xylose, mannose etc.) in $10 \mathrm{ml}$ basal medium (nutrient broth or $1 \%$ peptone water), $1 \mathrm{ml}$ $1 \%$ Andrade's indicator and $\mathrm{ph}$ 7.5] and incubated at $37^{\circ} \mathrm{C}$ for overnight. Acid production change the colour of medium to pink and gas production was concluded from a small bubble in inverted Durham's tube kept in the test tube.

Indole Production test: A loopful culture of selected potential isolates were inoculated in to tryptone broth (1\% Tryptone Water, $0.5 \mathrm{gm} \mathrm{NaCl}, 100 \mathrm{ml}$ distilled water and $\mathrm{pH}$ 7.4) and incubated at $37^{\circ} \mathrm{C}$ for overnight. After incubation, 3-4 drops of xylene were added in medium and shaken vigorously. The two layers were allowed to separate and $1 \mathrm{ml}$ of Kovac's reagent was added slowly. The formation of pink colour ring was considered as indicative of positive test.

Methyl Red test: A loopful culture of selected potential isolates were inoculated in to glucose phosphate broth (5 gm glucose, 5 gm $\mathrm{K}_{2} \mathrm{HPO}_{4}, 5 \mathrm{gm}$ peptone, $1000 \mathrm{ml}$ distilled water and $\mathrm{pH} 7$ ) and incubated at $37^{0} \mathrm{C}$ for $48-72$ hours. Following incubation, 
5 drops of methyl red indicator $(0.1 \mathrm{gm}$ methyl red in $300 \mathrm{ml} 95 \%$ ethanol) were in the medium. Development of red colour was considered as indicative of positive test.

Voges-Proskuer test: A loopful culture of selected potential isolates were inoculated in to glucose phosphate broth ( 5 gm glucose, 5 gm $\mathrm{K}_{2} \mathrm{HPO}_{4}, 5 \mathrm{gm}$ peptone, $1000 \mathrm{ml}$ distilled water and $\mathrm{pH} 7$ ) and incubated at $37^{\circ} \mathrm{C}$ for $48-72$ hours. . Following incubation, $0.6 \mathrm{ml}$ of $\alpha$-naphthol and $0.2 \mathrm{ml}$ $\mathrm{KOH}$ solution were added and shaken well. Development of red colour was considered as indicative of positive test.

Citrate Utilization test: The test determines ability of bacteria to use citrate as a sole source of carbon and energy. Heavy streaking of all potential isolates were done on the surface of Simmons's citrate agar slant $(0.2 \mathrm{gm}$ sodium citrate, $0.02 \mathrm{gm}$ $\mathrm{MgSO}_{4}, 0.5 \mathrm{gm} \mathrm{NaCl}, 0.1 \mathrm{gm}$ ammonium dihydrogen orthophosphate, $0.005 \mathrm{gm}$ bromothymol blue, $100 \mathrm{ml}$ distilled water, 4 gm agar, $\mathrm{pH}, 6.9)$ and incubate slant at $37^{\circ} \mathrm{C}$ for 48-72 hours. Development of deep blue colour within $24-48$ hours was considered as indicative of positive test.

Nitrate Reduction test: Organisms possessing nitrate reductase use nitrate as sole source of nitrogen will reduce nitrate to nitrite. All potential isolates were inoculated into peptone nitrate broth $(0.3 \mathrm{gm}$ meat extract, $0.5 \mathrm{gm}$ peptone, $0.1 \mathrm{gm}$ potassium nitrate, $100 \mathrm{ml}$ distilled water, $\mathrm{pH} \mathrm{7.4)} \mathrm{and}$ incubated at $37^{0} \mathrm{C} .0 .5 \mathrm{ml}$ of $\alpha$-naphtylamine reagent $(5.7 \mathrm{ml}$ glacial acetic acid, $14.3 \mathrm{ml}$ distilled water and $0.1 \mathrm{gm} \alpha$-naphtylamine) and sulphanilic acid reagent $(5.7 \mathrm{ml}$ glacial acetic acid, $14.3 \mathrm{ml}$ distilled water and 0.16 gm sulphanilic acid).The development of red colour in 30 seconds was considered as indicative of positive test.

Gelatin Hydrolysis test: Gelatin is used in culture media for determining gelatinolysis by bacteria A loopful culture of selected potential isolates were inoculated in to nutrient gelatin agar tube (3 gm meat extract, $10 \mathrm{gm}$ peptone, $150 \mathrm{gm}$ gelatin, $1000 \mathrm{ml}$ distilled water, $\mathrm{pH}$ 7.2) and incubated at $37^{\circ} \mathrm{C}$ for $48-72$ hours. Following the incubation, the tubes are placed at $5-10^{\circ} \mathrm{C}$ for $30-60 \mathrm{~min}$. The test would be positive if the inoculated medium remains in a liquid state even after refrigeration, while control remains solidified.

Phenylalanine Deamination test: Heavy streaking of potential isolates were done on the surface of phenylalanine agar slant $(0.4$ gm DL-phenylalanine, 0.2 gm $\mathrm{Na}_{2} \mathrm{HPO}_{4}, 1$ gm $\mathrm{NaCl}, 200 \mathrm{ml}$ distilled water, $4 \mathrm{gm}$ agar, $\mathrm{pH}$ 7.4) and incubated at $37^{\circ} \mathrm{C}$ for $18-24$ hours. After incubation, 4- 5 drops of $10 \%$ aqueous ferric chloride were added on the surface of slant. Immediate appearance of an intense green colour indicates presences of phenyl pyruvic acid and was considered as indicative of positive test.

Starch Hydrolysis test: The presences of amylase in microorganism can determine from starch hydrolysis test. All potential isolates were culture on the starch agar plate (3.0 gm beef extract, 10.0 gm soluble starch, $12.0 \mathrm{gm}$ agar and $1000 \mathrm{ml}$ distilled water) as spot or line and incubated at $37^{\circ} \mathrm{C}$ for $48-72$ hours. Following incubation the plates were flooded with Lugol's iodine (2.5 gm iodine, $5 \mathrm{gm}$ potassium iodide, and $10 \mathrm{ml}$ distilled water). Appearance of clear colourless zone around growth was considered as indicative of positive test.

Catalase test: Catalase is an enzyme that spilt up hydrogen peroxide into oxygen and water. Catalase is present in high concentration in majority of aerobic organisms, but absent in most obligate anaerobes Heavy streaking of potential 
isolates were done on the surface of nutrient agar slant and incubate at $37^{\circ} \mathrm{C}$ for 24 hours. $1 \mathrm{ml}$ of hydrogen peroxide was then added over the growth on agar slant. Rapid appearance and sustained production of gas bubble constitute positive test.

Triple Sugar Iron (TSI) Agar test: Heavy streaking was done on the surface of TSI agar slant, and stab same culture into butt of the slant ( $3 \mathrm{gm}$ beef extract, $3 \mathrm{gm}$ yeast extract, $20 \mathrm{gm}$ peptone, $10 \mathrm{gm}$ lactose, 10 gm sucrose, 1 gm D-glucose monohydrate, $0.2 \mathrm{gm}$ iron sulphate, $5 \mathrm{gm}$ sodium chloride, $0.3 \mathrm{gm}$ sodium thiosulphate, $24 \mathrm{mg}$ phenol red, $13 \mathrm{gm}$ agar, $1000 \mathrm{ml}$ distilled water $1000 \mathrm{ml}$ and $\mathrm{pH} \mathrm{7.1)} \mathrm{and} \mathrm{incubated} \mathrm{at} 37^{\circ} \mathrm{C}$ for 24 hours. Appearance of yellow coloration of the medium was considered as a positive result for carbohydrate fermentation. If the medium in the butt of the tube turns yellow (acidic) and the medium in the slant remains red (alkaline), than it concludes that the organism being tested only ferments dextrose (glucose) whereas a yellow (acidic) colour in the slant and butt indicates that the organism tested ferments dextrose, lactose and/or sucrose. A red (alkaline) colour in the slant and butt indicates that the organism being tested is a non-fermenter. Hydrogen sulphide production results in a black precipitate in the butt of the tube. Gas production is indicated by splitting and cracking of the medium.

Ammonia Production: All potential isolates were inoculated into peptone nitrate broth ( 0.3 gm meat extract, 0.5 gm peptone, $0.1 \mathrm{gm}$ potassium nitrate, $100 \mathrm{ml}$ distilled water and $\mathrm{pH} 7.4$ ), red litmus paper was placed on top of tube and incubated at $37^{\circ} \mathrm{C}$ for 24hours. Following incubation, turning of red litmus strip turn into blue colour indicates production of ammonia.

\section{Eosin Methylene Blue (EMB) Agar plate:}

Heavy streaking of all potential isolates were done on the surface of EMB agar plate (10 gm peptone, $10 \mathrm{gm}$ lactose, $2 \mathrm{gm}$ dipotassium-mono-hydrogenphosphate, 0.065 gm methylene blue, $0.4 \mathrm{gm}$ eosin $\mathrm{y}$, $15 \mathrm{gm}$ agar, $1000 \mathrm{ml}$ distilled and $\mathrm{pH} \mathrm{7)}$ ) and incubated at $37^{\circ} \mathrm{C}$ for 24 hours. Appearance of green metallic sheen colonies are considered as indicative of positive result on EMB.

Macconkey Agar plate: Heavy streaking of all potential isolates were done on the surface of Macconkey agar plate $(10 \mathrm{gm}$ lactose, $5 \mathrm{gm} \mathrm{NaCl}, 3 \mathrm{gm}$ peptone, $1,5 \mathrm{gm}$ bile salt, 0,03 gm neutral red, $0.001 \mathrm{gm}$ crystal violet, $13 \mathrm{gm}$ agar, $1000 \mathrm{ml}$ distilled water and $\mathrm{pH} 7$ ) and incubate at $37^{\circ} \mathrm{C}$ for 24 hours. Appearance of pink colour colonies was considered as an indicative of positive result i.e. lactose fermenter bacteria

Casein Hydrolysis: All potential isolates were cultured on the skim milk agar plate ( 5 gm casein, 2.5 gm yeast extract, 1 gm skim milk powder (no inhibitors), 1 gm glucose, $15.5 \mathrm{gm}$ agar, $1000 \mathrm{ml}$ distilled water and $\mathrm{pH} 7$ ) as spot or line and incubated at $37^{\circ} \mathrm{C}$ for 48-72 hours. Following incubation, appearance of clear colourless zone around growth is indicative of positive test.

Blood Agar Plate: All potential isolates were cultured on the blood agar plate $(3 \mathrm{gm}$ beef extract, $5 \mathrm{gm}$ peptone, $10 \mathrm{ml}$ blood, 15 gm agar 10,1000ml distilled water and $\mathrm{pH}$ 7) as spot or line and incubated at $37^{\circ} \mathrm{C}$ for 48-72 hours. Following incubation, appearance of clear zone of haemolysis around growth is indicative of positive test.

Oxidase: Heavy streaking of all potential isolates on surface of nutrient agar slant (3 gm beef extract, $5 \mathrm{gm}$ peptone $5 \mathrm{~g}, 15 \mathrm{gm}$ agar, $1000 \mathrm{ml}$ distilled water and $\mathrm{pH} \mathrm{7)}$ and incubated at $37^{\circ} \mathrm{C}$ for 24 hours. Following 
incubation, a colony was picked up and a smear was made on a filter paper moistened with $1 \%$ tetraethyl phenylenediamine dihydrochloride solution. Formations of violet colour within 45-60 seconds were considered as indicative positive result.

\section{Characterization of Lipase for Optimum Activity}

\section{Effect of pH on lipase activity}

Studies were done to evaluate the effect of $\mathrm{pH}$ on lipase activity. The crude enzyme used for assay was the culture broth after separation of cells and particles. The enzyme was normally stored at $4^{\circ} \mathrm{C}$ until used. Optimal $\mathrm{pH}$ for enzyme activity was determined by incubating the reaction mixture at $37^{\circ} \mathrm{C}$ in buffer solutions of $\mathrm{pH}$ values ranging from 6 to 9 , keeping other parameters same. Effect of $\mathrm{pH}$ on lipase action was analyzed by substituting the buffer in reaction mixture with the different buffers for different $\mathrm{pH}$ (Phosphate Buffer $(0.1 \mathrm{M})$ for $\mathrm{pH}-6,6.5,7,7.5,8,8.5$; Ammonia Buffer (0.1M) for $\mathrm{pH}-9$ ) (Tembhurkar et al., 2012).

\section{Optimization of temperature for lipase production}

Studies were done to evaluate the effect of temperature on lipase activity. Optimal temperature for enzyme activity was determined by incubating the reaction mixture at varying temperature in range 25 to $55^{\circ} \mathrm{C}$ keeping other parameters same. (Tembhurkar et al., 2012).

\section{Results and Discussion}

\section{Sample Collection and Primary Screening for Lipase Producing Bacteria}

A total of 3 samples were collected from 3 different sites with vegetable oil spillage and total of 26 different isolates producing lipase were obtained on TBA plate. An isolates showing clear zone of hydrolysis on TBA plate was considered as an indicative of lipase producer (Lawrence 1967). Table 2, shows the number of isolates showing zone of hydrolysis after 24 hours of incubation on TBA plate obtained from respective sampling site and the specific codes designated to all isolates obtained. Figure 3, shows the zone of hydrolysis obtained around isolate B4 on TBA plate. Diameter of zone of hydrolysis was measured, and the isolates with high diameter of zone of hydrolysis (more than $1 \mathrm{~mm}$ ) were subjected for further studies considering them as potential isolates. Table 3, shows the list of potential isolates selected for further studies selected on basis of their hydrolysis zone diameter.

\section{Secondary Screening to Determine Enzyme Units by Shake Flask Study}

The potential isolates selected on basis of high diameter of zone of hydrolysis on TBA plate from primary screening were further evaluated for the determining the activity of lipase they produce under fermentative conditions. Enzyme Units were determined by the slight modification of method described by Arima et al., (1972). The assay was carried out at $37^{\circ} \mathrm{C}$ and $\mathrm{pH} 7.5$. Results showed that EU of lipase produced by isolate A2 was $12.2 \mathrm{EU} / \mathrm{mL}$, of B4 was 13.2 $\mathrm{EU} / \mathrm{mL}$, of $\mathrm{C} 1$ was $11.9 \mathrm{EU} / \mathrm{mL}$ and for $\mathrm{C} 2$ it was $12.2 \mathrm{EU} / \mathrm{mL}$. It was evident form the result that all isolates subjected to study were producing lipase enzyme more than 11 EU/ml. Figure 4, shows the graphical representation of EU/ml of lipase produced by potential isolates.

\section{Characterization of Potential Isolates}

Morphological and biochemical characterization of potential isolates were studied for partial identification of isolates. Bergey's Manual of Systematic Bacteriology ( $2^{\text {nd }}$ edition) was used as a 
reference for identification based on the result of various biochemical tests. B4 and $\mathrm{C} 1$ isolates from 4 selected isolates were Gram positive while remaining A2 and C2 were Gram negative. The Gram positive isolates were found to show big thin rods and typical colony of Bacillus. These isolates were endospore forming. The isolates A2 and C2 were Gram negative short rods. Isolate $\mathrm{B} 4$ and $\mathrm{C} 1$ were identified as belongs to genus Bacillus, while other isolates required further characterization for their identification. Further, as describe by Feng et al., (2011)16s rRNA gene sequencing is necessary for specific identification of isolates. Table 4, shows the morphological characteristics of potential isolates and Table 5, shows the biochemical characteristics of the same.

\section{Characterization of Lipase For Optimum Activity}

\section{Effect of pH on lipase activity}

Lipases produced by potential isolates were characterized for its optimum activity. Lipases were found to give better activity at slightly alkaline $\mathrm{pH}$. The optimum activity given by lipase produced by isolates A2, B4, $\mathrm{C} 1$ \& $\mathrm{C} 2$ was at $\mathrm{pH} 7.5,8,8$ and 7.5 respectively. Figure 5, shows the graphical representation of effect of $\mathrm{pH}$ on enzyme activity.

Table.1 Analytical methods for determining lipases (Schmid and Verger, 1998).

\begin{tabular}{|c|c|c|c|}
\hline Methods & Principle & Advantages & Disadvantages \\
\hline $\mathrm{pH}$ salt & $\begin{array}{l}\text { Potentiometric determination of } \\
\text { fatty acids liberated upon } \\
\text { hydrolysis }\end{array}$ & $\begin{array}{l}\text { Contionous kinetics } \\
\text { methods for the } \\
\text { determination of initial } \\
\text { rates }\end{array}$ & $\begin{array}{l}\text {-Expensive equipment } \\
\text {-Added emulsifiers often } \\
\text { modify reaction conditions } \\
\text {-Not applicable under } \\
\text { acidic pH conditions }\end{array}$ \\
\hline Back titration & $\begin{array}{l}\text { Titration of liberated fatty acids } \\
\text { after defined exposure to lipase } \\
\text { action }\end{array}$ & Simple & -No continuous kinetic data \\
\hline Colorimetry & $\begin{array}{l}\text { Liberation of a reporter group } \\
\text { from a synthetic ester (e.g. } p \text { - } \\
\text { nitrophenyl palmitate or } \\
\text { dilauryl glycerol resorufin } \\
\text { ester) }\end{array}$ & $\begin{array}{l}\text { Fast and automatic } \\
\text { kinetic measurements }\end{array}$ & -Unnatural substrates \\
\hline $\begin{array}{l}\text { Determining the } \\
\text { hydrolysis of } \\
\text { lipid films } \\
\text { spread at } \\
\text { air/water } \\
\text { interface }\end{array}$ & $\begin{array}{l}\text { Hydrolysis of a lipid monolayer } \\
\text { at constant surface pressure } \\
\text { with continuous supply of } \\
\text { substrate ( zero order trough) }\end{array}$ & $\begin{array}{l}\text { Kinetic measurements in } \\
\text { the absence of added } \\
\text { emulsifier and under } \\
\text { controlled "interfacial } \\
\text { quality" }\end{array}$ & $\begin{array}{l}\text {-Expensive equipment } \\
\text {-Time consuming } \\
\text {-Trained experimentalist } \\
\text { necessary }\end{array}$ \\
\hline
\end{tabular}


Table.2 Number of lipase producing bacteria isolated from different sampling site.

\begin{tabular}{|l|l|l|l|}
\hline $\begin{array}{l}\text { Sr. } \\
\text { No }\end{array}$ & Sampling Site & $\begin{array}{l}\text { Number of } \\
\text { isolates } \\
\text { obtained }\end{array}$ & Codes designated to isolates \\
\hline 1 & Gokul Fafda Centre, Buhari & 09 & A1, A2, A3, A4, A5, A6, A7, A8, A9 \\
\hline 2 & Jalaram Khichdi, Bardoli & 07 & B1, B2, B3, B4, B5, B6, B7 \\
\hline 3 & Hari-om Hotel, Bardoli & 10 & C1, C2, C3, C4, C5, C6, C7, C8, C9, C10 \\
\hline
\end{tabular}

Table.3 List of potential lipase producing bacteria.

\begin{tabular}{|c|c|c|}
\hline Sr. No & Isolate & $\begin{array}{c}\text { Diameter of zone of hydrolysis } \\
(\mathbf{m m})\end{array}$ \\
\hline 1 & $\mathrm{~A} 2$ & 1.4 \\
\hline 2 & $\mathrm{~B} 4$ & 1.6 \\
\hline 3 & $\mathrm{C} 1$ & 1.3 \\
\hline 4 & $\mathrm{C} 2$ & 1.2 \\
\hline
\end{tabular}

Table.4 Morphological characteristics of potential isolates

\begin{tabular}{|l|c|c|c|c|}
\hline \multirow{2}{*}{ Characteristics } & \multicolumn{4}{|c|}{ Isolates } \\
\cline { 2 - 5 } & A2 & B4 & C1 & C2 \\
\hline Size & Small & Large & Large & Large \\
\hline Shape & Round & Round & Round & Irregular \\
\hline Margine & Even & Even & Even & Undulate \\
\hline Elevation & Convex & Convex & Flate & Convex \\
\hline Texture & Smooth & Smooth & Smooth & Smooth \\
\hline Consistency & Moist & Moist & Moist & Moist \\
\hline Opacity & Opaque & Opaque & Opaque & Opaque \\
\hline Gram's nature & Gram $-\mathrm{ve}$ & Gram +ve & Gram +ve & Gram -ve \\
\hline
\end{tabular}


Table.5 Biochemical characteristics of potential isolates

\begin{tabular}{|c|c|c|c|c|}
\hline \multirow{2}{*}{ Biochemical tests } & \multicolumn{4}{|c|}{ Isolates } \\
\hline & $\mathbf{A 2}$ & B4 & C1 & C2 \\
\hline Glucose utilization test & + & + & + & + \\
\hline Maltose utilization test & + & + & + & + \\
\hline Sucrose utilization test & + & + & + & + \\
\hline Lactose utilization test & - & - & - & - \\
\hline Xylose utilization test & - & - & - & - \\
\hline Mannitol utilization test & - & - & - & - \\
\hline Indol production test & - & - & - & - \\
\hline Methyl red test & - & - & - & - \\
\hline Voges - proskuer test & + & - & + & - \\
\hline Citrate utilization test & - & - & - & - \\
\hline Nitrate reduction test & + & - & + & + \\
\hline Gelatine hydrolysis test & - & - & - & - \\
\hline Urea hydrolysis test & - & - & - & - \\
\hline $\begin{array}{l}\text { Phenylalanine } \\
\text { Deamination test }\end{array}$ & - & - & - & - \\
\hline Catalase test & + & + & + & + \\
\hline Oxidase test & + & + & + & + \\
\hline \begin{tabular}{|ll} 
TSI test: & -Butt \\
& - Slant \\
& $-\mathrm{H}_{2} \mathrm{~S}$ \\
& - GaS \\
\end{tabular} & $\begin{array}{c}\text { Acidic } \\
\text { Acidic } \\
- \\
- \\
\end{array}$ & $\begin{array}{c}\text { Acidic } \\
\text { Acidic } \\
- \\
- \\
\end{array}$ & $\begin{array}{c}\text { Alkaline } \\
\text { Acidic } \\
- \\
- \\
\end{array}$ & $\begin{array}{c}\text { Acidic } \\
\text { Alkaline } \\
- \\
- \\
\end{array}$ \\
\hline Cetrimide agar plate & - & - & - & - \\
\hline
\end{tabular}

Key: '+' indicates positive test and '-' indicates negative test.

Fig.1 Mechanism of Lipase action (Source: Jaeger and Reetz, 1998).

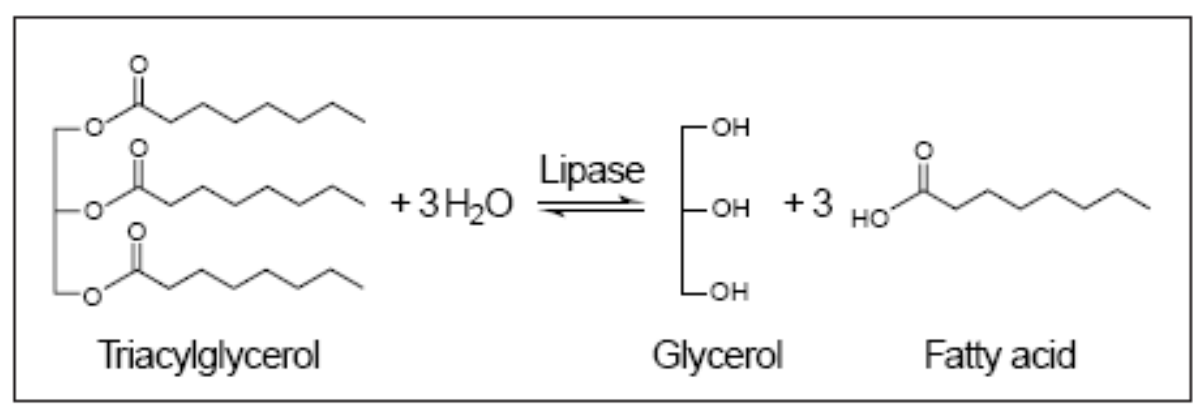


Fig.2 Structure of lipase from Pseudomonas aeruginosa (Source: Jaeger and Reetz, 1998).

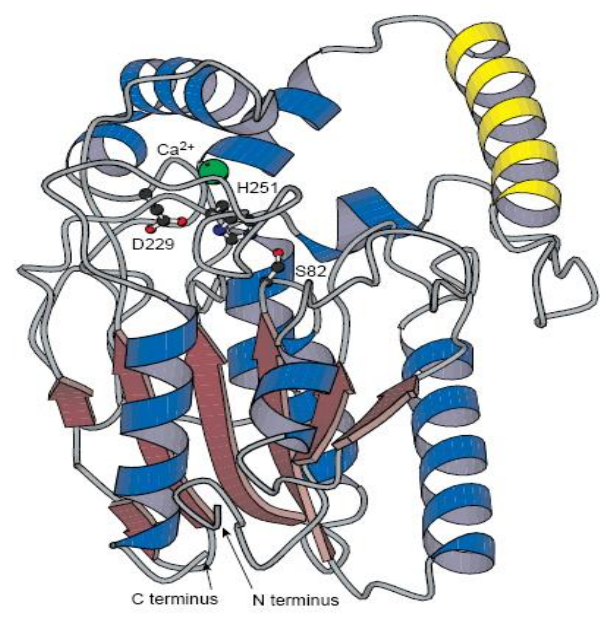

Fig.3 Shows the hydrolytic activity of lipase producer (isolate B4) on TBA plate.

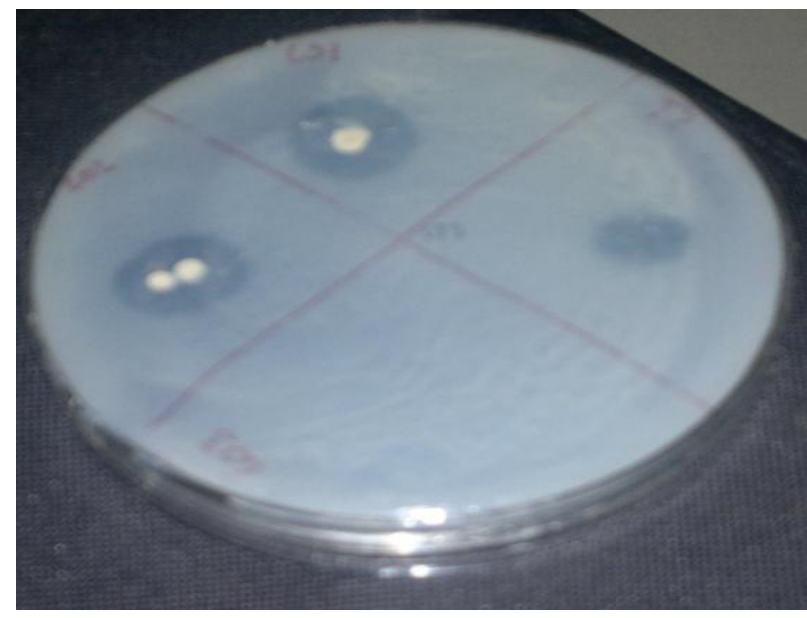

Fig.4 Eu/ml of lipase produced by potential isolates.

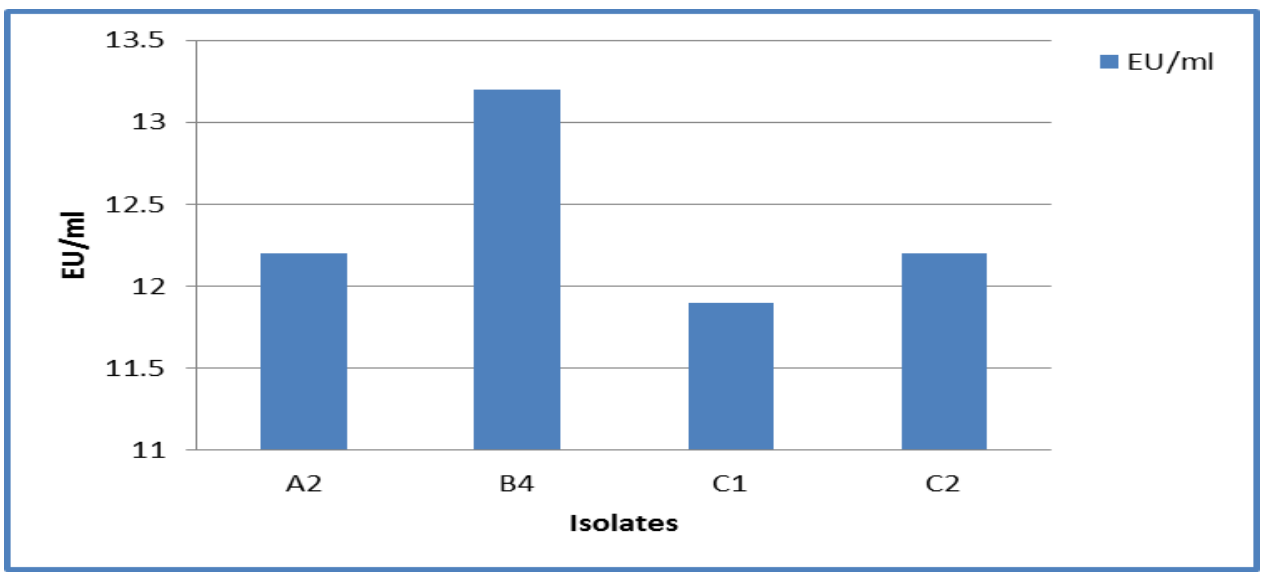


Fig.5 Effect of $\mathrm{pH}$ on lipase activity.

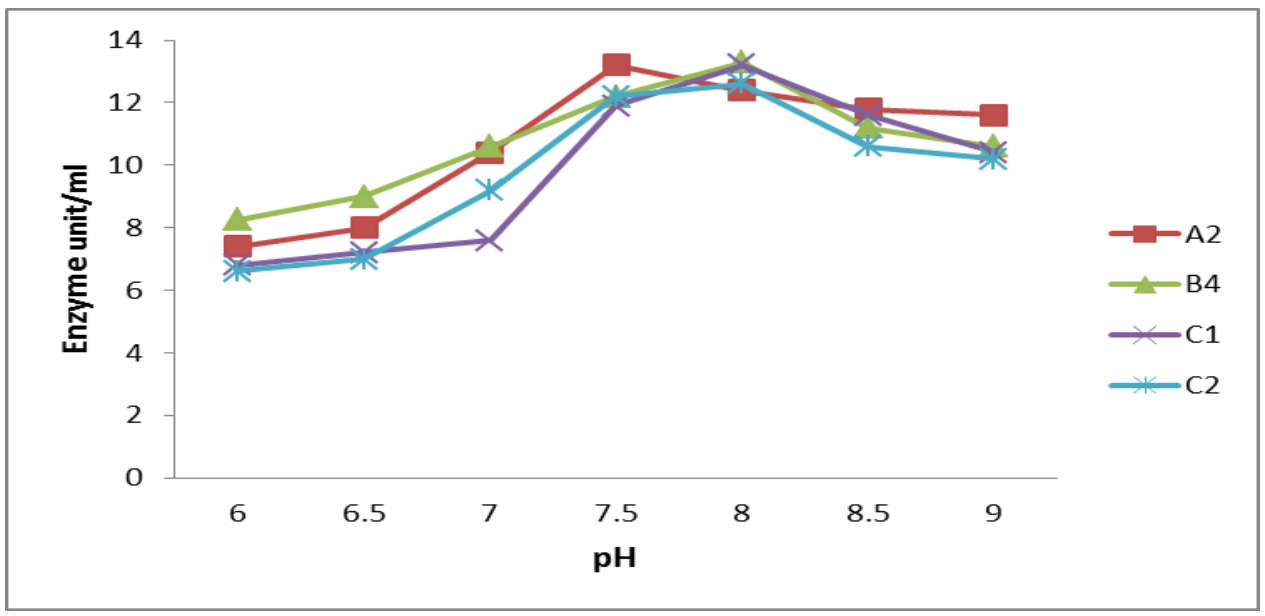

Fig.6 Effect of temperature on lipase activity.

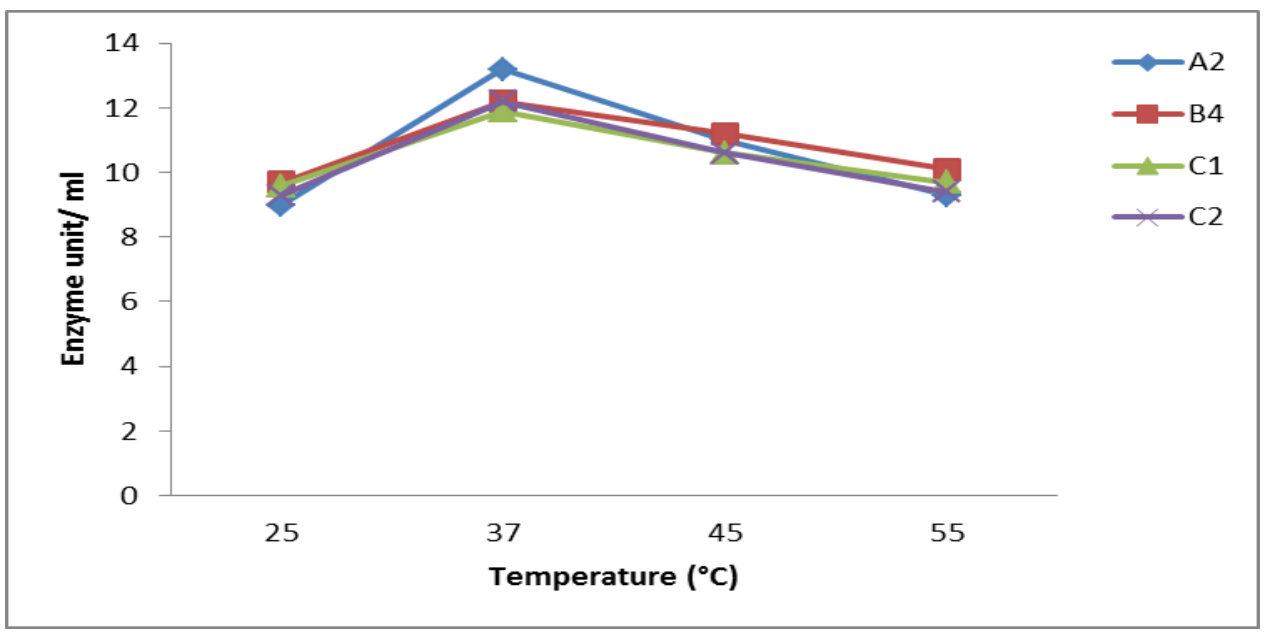

\section{Effect of temperature on lipase activity}

Lipases produced by potential isolates were also analyzed for its optimum activity at different temperatures. Lipases were found to give better activity at $37^{\circ} \mathrm{C}$ temperature. The optimum activity given by lipase produced by isolates $\mathrm{A} 2, \mathrm{~B} 4, \mathrm{C} 1$ and $\mathrm{C} 2$ was at $37^{\circ} \mathrm{C}$ respectively. Figure 5 , shows the graphical representation of effect of temperature on enzyme activity.

The existence of lipase producing microorganisms in diverse environment such as industrial wastes, vegetable oil processing factories and spillage sites, dairies, soil contaminated with oil, oilseeds, and decaying food, compost heaps, coal tips, and hot springs has been studied (Wang et al., 1995).

Morphological and physiologicalbiochemical characterization like Gram satin, oxidase test, catalase test, VogesProskauer test, methyl red test, indole test, glucose fermentation test, hydrogen sulfide production, and hydrolysis of starch etc. are performed for partial identification of bacteria. Bergey's Manual of systematic bacteriology is use as a reference for 
comparing the cjaracteristics (Feng et al., 2011). Further, as describe by Feng et al., (2011)16s rRNA gene sequencing is necessary for specific identification of isolates.

Generally, bacterial lipases have neutral or alkaline pH optima (Gupta et al., 2004) with the exception of $P$. fluorescens SIK W1 lipase, which has an acidic optimum at $\mathrm{pH}$ 4.8 (Andersson et al., 1979). Lipases from Bacillus stearothermophilus SB- 1, B. atrophaeus SB-2 and B. licheniformis SB-3 are active over a broad $\mathrm{pH}$ range 3-12 (Bradoo et al., 1999). Bacterial lipases possess stability over a wide range, from $\mathrm{pH}$ 4 to $\mathrm{pH} 11$ (Wang et al., 1995).

Also bacterial lipases generally have temperature optima in the range $30-60^{\circ} \mathrm{C}$ (Wang et al., 1995). However, reports exist on bacterial lipases with optima in both lower and higher ranges. Thermal stability data are available only for species of Bacillus, Chromobacterium, Pseudomonasand Staphylococcus (Gupta et al., 2004).

\section{References}

Andersson, R.E., Hedlund, G.B., Jensson, V. 1979. Thermal inactivation of a heatresistant lipase produced by the psychrotrophic bacterium Pseudomonas fluorescens. J. Dairy Sci., 62: 361-367.

Arima, K., H. Wen and T. Beppu. 1972. Lipase from Bacillus T Agric. Biol. Chem., 11: 1913-1917.

Sumanjelin, B., C.S.V. Ramachandra Rao, R. SatishBabu. 2013. Isolation, Characterization of Lipase Producing Bacteria from Crude Rice Bran Oil and Optimization studies by Response Surface Methodology (RSM). J. Chem. Biol. Physical Sci., 3(1): 289-296.

Bajpai, P. 1999. Application of enzymes in the pulp and paper industry
Biotechnol.Prog., 15: 147-157.

Barbaro, S.E., Trevors, J.T., Inniss, W.E. 2001. Effects of low temperature, cold shock, and various carbon sources on esterase and lipase activities and exopolysaccharide production by a psychrotrophic Acinetobacter sp. Can. J. Microbiol., 47: 194-205.

Benjamin, S., Pandey, A. 2001. Isolation and characterization of three distinct forms of lipases from Candida rugosa produced in solid state fermentation. Braz. Arch. Biol. Technol. 44: 213-221

Berglunnd. 2001. Controlling lipase enantioselectivity for organic synthesis. Biomolecular Engineering. 18: 13-22.

Bradoo, S., Saxena, R.K., Gupta, R. 1999. Two acidothermotolerant lipases from new variants of Bacillus spp. World J. Microbiol. Biotechnol., 15: 87-91.

Brune, A.K., Gotz, F. 1992. Degradation of lipids by bacterial lipases In: Winkelman G (ed) Microbial degradation of natural products. $\mathrm{VCH}$, Weinhein, pp 243-266.

Cai-hong, W., Run-fang, G., Hong-wei, Y., Ying-min, J. 2008. Cloning and Sequence Analysis of a Novel ColdAdapted Lipase Gene from Strainlip35 (Pseudomonas sp.) Agri. Sci. China, 7(10): 1216-1221

Dong, H., Gao, S,. Han, S., Cao, S. 1999. Purification and characterization of a Pseudomonas sp. lipase and its propertiesin non-aqueous media. Appl. Microbiol. Biotechnol., 30: 251-256.

Mobarak-Qamsari, E., R. KasraKermanshahi, Z. Moosavi-nejad. 2011. Isolation and identification of a novel, lipase-producing bacterium, Pseudomnas aeruginosa KM110. Iran J. Microbiol., 3(2): 92-98.

Feng, W., Wang, X.Q., Zhou, W., Liu, G.Y., Wan, Y.J. 2011. Isolation and characterization of lipase-producing bacteria in the intestine of the 
silkworm, Bombyx mori, reared on different forage. $J$. Insect Science 11:135 available online: insectscience.org/11.135

Fleming, H.P. 1991. Mixed Cultures in Vegetable Fermentations. In: Mixed Cultures in Biotechnology, Zeikus, J.G. and E.A. Johnson (Eds.).McGrawHill, New York, pp: 69-103

Fryer, T.F., Lawrence, R.C., Reiter, B. 1967. Methods for Isolation and Enumeration of Lipolytic Organisms. $J$. Dairy Sci., 50(4): 477-484.

Ghosh, P.K., Saxena, R.K., Gupta, R., Yadav, R.P., Davidson, W.S. 1996. Microbial lipases: production and applications. Sci. Prog. 79: 119-157.

Gilham, D., R. Lehner. 2005.Techniques to measure lipase and esterase activity in vitro.Methods, 36: 139-147.

Gitleson, T., Bauer, M. and Adlercreutz, P. 1997. Adsorption of lipase on polypropylene powder. Biochem. Biophysics. Acta, 1345: 188-196.

Gupta, R., N. Gupta, P. Rathi. 2004. Bacterial lipases: an overview of production, purification and biochemical properties. Appl. Microbiol. Biotechnol., 64: 763-781.

Hasan, F., Shah, A.A., Hameed, A. 2006. Industrial applications of microbiallipases. Enzyme and Microbial. Technolog., 39: 235-251.

Jaege, K.E., T. Eggert. 2002. Lipases for biotechnology. Curr. Opi. Biotechnol., 13: 390-397.

Jaeger, K.E., M.T. Reetz. 1998. Microbial lipases form versatile tools for Biotechnology. Trends in Biotechnol., 16(9): 396-403.

Jaeger, K.E., Ransac, S,. Dijkstra, B.W., Colson, C., van Heuvel, M., Misset, O. 1994. Bacterial Lipases FEMS

Microbiol. Rev., 15: 29-63.

Khyami-Horani, H. 1996. Thermotolerant strain of Bacillus licheniformis producing lipase. World J. Microbial. Biotechnol., 12: 399-401.

Kojima, Y., Kobayashi, M., Shimizu, S. 2003. A Novel Lipase from Pseudomonas fluorescens HU380: Gene Cloning, Overproduction, Reneturation-Activation, Two-Step Purification, and Characterization. $J$. Biosci. Bioengi., 96 (3): 242-249.

Kulkarni, N., Gadre, R.V. 2002. Production and properties of an alkaline, thermophilic lipase from Pseudomonas fluorescens NS2W. J. Industrial Microbiol. Biotechnol., 28(6): 344-8.

Lotti, M., Monticelli, S., Montesinos, J.L., Brocca, S., Valero, F., Lafuente, J. 1998. Physiological control on the expression and secretion of Candida rugosa lipase. Chem. Phys. Lipids, 93:143-148.

Masahiko, Masahiro, A.K., Takasi, K., Kenji, M., Ayari, M. et al. 1995. Process for preparation of polyol fatty acid ester and glyceride mixture obtained. Eur Pat., EP-658629.

Metzger, J.O., Bornscheuer, U. 2006. Lipids as renewable resources: Current state of chemical and biotechnological conversion and diversification. Appl. Microbiol. Biotechnol. 71: 13-22.

Nakamura, Yoda, K.M., Fukase, T. 1994. Treatment process for drainage containing fats and oils. Japan Patent, JP-06246295.

http://www19.ipdl.inpit.go.jp/PA1/cgibin/PA1DETAIL.

Nashif, S.A., Nelson, F.E. 1953. The lipase of Pseudomonas fragi II: factors affecting lipase production. J. Dairy Sci., 36: 471-480.

Noble, M.E., M.A. Cleasby, L.N. Johnson, M.R. Egmond, L.G.J. Frenken. 1993. The crystal structure of triacylglycerol lipase from Pseudomonas glumaereveals a partially redundant catalytic aspartate Febs, letters, 331 (1- 
2): 123-128

Pandey, A.S., Benjamin, C.R. Soccol, P. Nigam, N. Krieger, V.T. Soccol. 1999. The realm of microbial lipases in biotechnology. Biotechnol. Appl. Biochem., 29: 119-131.10

Peterson, S.B., F, Drabløs. 1994. A sequence analysis of lipases, esterases, and related proteins In: Lipases-their structure, biochemistry, and application, ed.P. Woolley, and S.B. Peterson Cambridge Cambridge University Press. pp , 23-48.

Rathi, P., Saxena, R.K., Gupta, R. 2001. A novel alkaline lipase from Burkholderia cepacia for detergent formulation. Process Biochem., 37: 187-192.

Schmid, R.D., R. Verger. 1998. Lipases: Interfacial Enzymes with Attractive Applications. Angew Chem. Int. Ed. 37: 1608-1633.

Seitz, E.W. 1974. Industrial Applications of Microbial Lipases: A Review. Journal of the American Oil Chemists' Society. 51 (2): 12-16.

Sharma, D., Sharma, B., Shukla, A.K. 2011. Biotechnological Approach of Microbial Lipase. Review Biotechnol., 10: 23-40.

Sharma, R., Chisti, Y., Banerjee, U.C. 2001. Production, purification, characterization and applications of lipase. Biotechnol. Adv., 19: 627-662.

Sharma, R., Soni, S.K., Vohra, R.M., Jolly, R.S., Gupta, L.K., Gupta, J.K. 2002. Production of extracellular alkaline lipase from aBacillus sp. RSJ1 and its application in ester hydrolysis. Ind. $J$.
Microbiol., 42: 49-54.

Shelley, A.W., H.C. Deeth, I.C. MacRae 1987. Review of methods of enumeration, detection and isolation of lipolytic microorganisms with special reference to dairy applications.

Sugihara, A., Tani, T., Tominaga, Y. 1991. Purification and characterization of a novel thermostable lipase from Bacillus sp. J. Biochem., 109: 211-216.

Sumanjelin, B., Ramachandra Rao, C.S.V. and Satish Babu, R. 2013. Isolation, Characterization of Lipase Producing Bacteria from Crude Rice Bran Oil and Optimization studies by Response Surface Methodology (RSM). J. Chem. Biol. Physical Sci., 3(1): 289-296.

Sztajer, H., Maliszewska, I., Wieczorek, J. 1988. Production of exogenous lipases by bacteria, fungi, and actinomycetes, Enzyme and Microbial Technol., 10(8): 492-97.

Thomson, C.A., Delaquis, P.J., Mazza, G. 1999. Detection and Measurement of Microbial Lipase Activity: A Review. Critical Reviews in Food Sci. Nutri., 39(2): 165-187.

Tembhurkar, V.R., Kulkarniand, M.B. and Peshwe, S.A. 2012. Optimization of Lipase Production by Pseudomonas spp. in submerged batch process in shake flask culture. Sci. Res Reporter, 2(1): 46-50.

Wang, Y., Srivastava, K.C., Shen, G.J., Wang, H.Y. 1995. Thermostable alkaline lipase from a newly isolated thermophilic Bacillus, strain A30-1 (ATCC 53841). J. Ferment Bioeng., 79: 433-438.

\section{How to cite this article:}

Miral Patel, Jemisha Mistry, Suraj Desai, Swetal Patel and Shreya Desai. 2016. Isolation and Characterization of Lipase producing Bacteria from Vegetable Oil Spillage Site. Int.J.Curr.Microbiol.App.Sci. 5(8): 214-232. doi: http://dx.doi.org/10.20546/ijcmas.2016.508.023 